\title{
st \\ O ateliê musical de Claudio Ptolomeu
}

Cynthia Gus mão

\begin{abstract}
$\stackrel{\leftrightarrow}{\dddot{0}}$
RESUMO

A música é uma arte privilegiada no que diz respeito ao campo técnico, uma vez que desde recuados tempos na história dispôs de instrumentos para a sua realização. Os instrumentos musicais também conduziram a investigações acústicas desde a Antiguidade até a era moderna, fazendo o papel tanto de dispositivos de observação do fenômeno musical quanto de modelos de representação do som. $\mathrm{O}$ artigo investiga a abordagem de Ptolomeu, na Harmônica, de diferentes métodos de investigação que surgem entre a concepção pitagórica da música, com seu fundamento aritmético, e a aristoxeniana, que conduz a questão para o âmbito das faculdades humanas da percepção auditiva e do entendimento. Mas também dando ao instrumento musical um papel importante do ponto de vista empírico e matemático. O tratado tem importância crucial, reunindo todo o saber da ciência harmônica antiga e indo além da própria ciência musical expondo a própria noção de harmonia universal dos antigos.
\end{abstract}

Palavras- Ghave • Música. Harmônica. Pitagorismo. Acústica. Instrumento. Aristóxeno. Hélicon.

Ptolomeu.

\section{INTRODUÇÃO}

Os historiadores da ciência não costumam incluir a música em seu campo de estudos, talvez porque na modernidade o âmbito de investigação dessa técnica e arte tenha se deslocado radicalmente para a estética. Mas também o conceito geral e mesmo o termo ciência acontecem em um quadro moderno; como sublinha o historiador inglês Geoffrey Lloyd, os antigos utilizavam expressões como filosofia, investigação da natureza, especulação ou saber para suas investigações científicas, ${ }^{\mathbf{1}}$ e cada autor concebia a seu modo "a natureza das investigações que empreende, seus objetivos e métodos" (Lloyd, 1990, p. 7-8).

Claudio Ptolomeu (c. 90-168 d.C.) é conhecido como matemático e astrônomo, mais um cientista na concepção moderna que um filósofo. Mas os autores antigos, em especial a partir do período helenístico, incluem a "física" entre os ramos da filosofia. Além disso, Ptolomeu escreveu livros especificamente sobre questões epistemológicas, que são explicitadas no método que emprega na Harmônica.

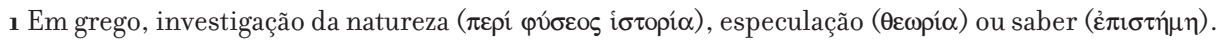


No segundo capítulo do Livro 2 da Fúsica, Aristóteles faz a distinção entre as disciplinas físicas e matemáticas, em que os objetos matemáticos podem ser estudados de maneira abstrata, mas não os corpos naturais ou físicos, que devem ser investigados pela física. Para Aristóteles, existem ciências que trabalham com objetos naturais, de maneira matemática.

Isso aparece nas mais físicas dentre as matemáticas: a óptica, a harmônica e a astronomia, pois, de certo modo, elas se comportam de maneira inversa à geometria; pois a geometria estuda a linha física, mas ela não é física - ao contrário, a óptica estuda a linha matemática, não enquanto matemática, mas enquanto física (Aristóteles, 1996, 2, 2, 194ą).

Portanto, as áreas às quais se dedicou Ptolomeu estão entre "as mais físicas das matemáticas" e trabalham diretamente com a natureza. Ele é especialmente reconhecido por suas obras de astronomia, por ter apresentado uma teoria coerente e com alto grau de predição. Por exemplo, no caso das predições da Lua, o modelo ptolomaico é considerado "suficientemente exato, mesmo se, tratado como explicação física, ele entre em contradição flagrante com os fatos" (Lloyd, 1990, p. 149). No conjunto da obra ptolomaica, a Harmônica é considerada uma obra menor. Contudo, ela merece atenção especial, não por expor as sutilezas dessa ciência ou filosofia, mas pelo fato do autor explicitar ali alguns de seus procedimentos científicos e metodologias.

O historiador francês Pierre Duhem, no início do século xx, propôs uma interpretação que se tornou bastante influente, na qual divide as posturas das ciências antigas entre "instrumentalista" e "realista" (cf. Duhem apud Lloyd, 1991, p. 276). A primeira posição estaria presente na noção grega de "salvar as hipóteses", ${ }^{2}$ ou "salvar as aparências" ( $\sigma \omega ́ \zeta \varepsilon \imath v ~ \tau \alpha ̀ ~ \varphi \alpha \imath v o ́ \mu \varepsilon v \alpha)$. Para Duhem, Ptolomeu seria um caso típico de cientista instrumentalista, na medida em que, em suas obras de astronomia, ele teria revisado ou rejeitado o movimento dos astros de modo a acomodar leis pré-estabelecidas aos cálculos matemáticos. Esse ponto de vista de Duhem foi criticado em $197^{8}$ por Geoffrey Lloyd no artigo "Saving the appearences" (cf. Lloyd, 1991, p. 254-77). O autor aponta, entre suas objeções, que havia um pluralismo de concepções na ciência antiga e que os papéis do astrônomo e físico não eram totalmente independentes, como Duhem havia proposto. Para Lloyd,

2 O significado grego para "hipótese" é diferente do nosso significado atual, de um enunciado que se refere a um ponto de partida ainda não comprovado. Já para os antigos gregos, "hipótese” é um modelo ou uma explicação. 
(...) se considerarmos algumas das maiores figuras (...) que mencionamos Eratóstenes e Posidônio em geofísica, Hiparco e Ptolomeu em astronomia, Aristóxeno, Ptolomeu e Porfírio em harmônica, e Ptolomeu, novamente, na óptica não há nada que sugira que eles tenham levantado dúvidas céticas radicais acerca do valor da percepção sensível para suas investigações (Lloyd, 1987, p. 272-3).

A posição de Duhem é igualmente relativizada por Sedeño na introdução que elaborou à sua tradução da obra As hipóteses dos planetas de Ptolomeu, escrita provavelmente com a intenção de trabalhar questões que não haviam sido contempladas de maneira satisfatória em obras anteriores. Apesar de, mesmo na Syntaxis, Ptolomeu ter demonstrado estar "consciente da importância da física e da necessidade de efetuar uma espécie de síntese de modo a evitar que as questões físicas ficassem à margem" (Sedeño, 1987, p. 35). Segundo a autora, em As hipóteses dos planetas, Ptolomeu busca alcançar uma explicação física do universo, em especial quando descreve os círculos que dirigem os movimentos celestes. Nesse momento, Ptolomeu teria rejeitado a teoria aristotélica em favor de noções vitalistas: "devemos supor que entre os corpos celestes cada planeta possui por si mesmo uma força vital, que ele se move por si mesmo e que ele comunica seu movimento aos corpos que lhe são unidos por natureza" (Ptolomeu, 1987, 2, cap. 7; Lloyd, 1990, p. 150).

Lloyd chama a atenção ainda para a Óptica de Ptolomeu, na qual os princípios descritos seriam conhecidos muito antes dele, mas que sua contribuição teria sido a de os haver "confirmado experimentalmente", ainda que ajustando-os à lei geral matemática. Como diz Lloyd, com a precariedade dos instrumentos de que dispunham os antigos, eles estavam certos em "confiar mais em seus métodos matemáticos que em suas observações" (1990, p. 157), mas isso não deixa margem para afirmar que Ptolomeu desqualificava completamente a observação.

\section{Ptolomeu e a filosofia}

Pouco se sabe da vida de Ptolomeu. Estima-se o período em que viveu a partir das observações astronômicas que ele fez no paralelo de Alexandria entre 127 d.C. e 1411 d.C. A Alexandria de Ptolomeu já não era a mesma do tempo em que lá viveu a plêiade de cientistas composta por Euclides (360-295 a.C.), Ctesibius (cerca de 285-222 a.C.) e tantos outros. Desde o século i a.C., a cidade vivia sob o regime dos imperadores romanos, que transformaram o Egito no celeiro do Império e a cidade tornara-se um centro comercial cosmopolita, entre Roma e África. Mas tanto a biblioteca quanto o museu ainda estavam em funcionamento. A obra de Ptolomeu evidencia o conjunto de conhe- 
cimentos e aptidões desenvolvido até então e a facilidade de acesso a informações que propiciava o ambiente da cidade. Em todas as áreas a que ele se dedicou, a quantidade de informação detalhada que ele consegue reunir é enorme. Esse momento privilegia cada vez mais as mensurações, que legitimam os avanços científicos, especialmente na geofísica, na óptica, na astronomia e na harmônica, seus principais campos de trabalho.

Alguns historiadores da filosofia classificam o período em que viveu Ptolomeu como eclético. Segundo eles, o ecletismo teria surgido após o helenismo, quando emergiram movimentos como epicurismo, estoicismo e ceticismo e antes do surgimento do neoplatonismo no século iıı. O termo eclético referir-se-ia tanto à filosofia dos romanos Cícero e Sêneca quanto à ciência de Ptolomeu e Galeno.

A denominação eclética ganhou uma conotação negativa, em especial na obra do filósofo alemão Edouard Zeller (1814-1908), que caracterizou a época como a de um vigor intelectual menor, concepção que foi muito divulgada (cf. Donini, 1996, p. 22-6). O ecletismo teria uma tendência a apaziguar as controvérsias que existiram na Antiguidade e, sobretudo, de resistir à exploração que os céticos haviam feito dos dissensos.

Lloyd chamou a exacerbação constante de rivalidade entre as teorias de "tradição grega da contestabilidade de uma tradição" (1987, p. 107). Segundo ele, já a partir do século IV d.C. essa tradição começou a esmaecer, e o equilíbrio de forças da tensão entre tradição e inovação voltou-se gradativamente para a tradição, cedendo lugar para a postura de referência à autoridade de grandes figuras do passado, como Pitágoras, Hipócrates, Platão e Aristóteles e, mais tarde, Galeno e Ptolomeu. Surgem os comentadores, que não têm como objetivo criticar os textos, mas apontar de que maneira eles contêm a verdade. Alguns desses autores "buscam mostrar como Platão e Aristóteles estavam em um acordo substancial, assim como no século iı d.C. Galeno também frequentemente busca reconciliar Platão e Hipócrates" (1987, p. 105). Essa deferência tornar-se-á uma tópica da retórica que passa a ter como ponto de partida a auctoritas dos antigos. $\mathrm{O}$ autor chama a atenção, no entanto, para o fato de que não devemos nos confundir com essa tópica retórica, pois Galeno e Ptolomeu, por exemplo, farão contribuições originais aos seus campos, "tanto como teóricos quanto como observadores" (1987, p. 106).

Autores como Dillon e Long restabeleceram alguns aspectos filosóficos importantes do ecletismo, em especial de cientistas práticos como Galeno e Ptolomeu.

Enquanto era adequado aos céticos representar filósofos doutrinários como proponentes de opiniões discrepantes radicais, cientistas práticos tinham interesse em descartar diferenças sutis entre conceitos e teorias de cujas bases gerais eles poderiam se apropriar como sustentação de suas metodologias (Dillon \& Long, 1996, p.10). 
Para os autores, Galeno e Ptolomeu teriam praticado o "reverso da estratégia dos céticos de opor as teorias umas às outras refutando assim todas". Esses cientistas teriam considerado a relação de reciprocidade que há entre observações controladas e postulados teóricos a fim de utilizar "de uma maneira inovadora os conceitos tradicionais no interesse de um novo tipo de filosofia da ciência” (Dillon \& Long, 1996, p. 10).

Ptolomeu marcou sua posição no campo da epistemologia na obra "Sobre o cri-

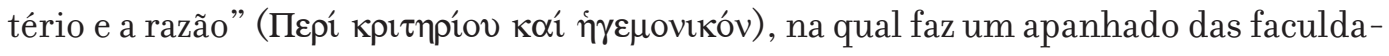
des cognitivas e suas funções e também das formas como interagem entre o corpo e a alma na constituição humana. Essa epistemologia será colocada em prática naquela que talvez tenha sido sua obra mais significativa, a Harmônica (cf. Solomon, 2000, p. xxx). Como chama a atenção Long, na Harmônica a combinação de indução e dedução remete à prática da "disposição científica" de coleta e divisão de "Sobre o critério" (Long, 1996, p. 204).

Ptolomeu busca, como cientista, estabelecer critérios confiáveis para conhecer seus objetos. Ele não nomeia filósofos ou oponentes, apenas seleciona elementos da tradição filosófica e, a partir deles, assume posições próprias. Isso fica claro na sua abordagem da controvérsia entre pitagóricos e aristoxenianos.

\section{UMA APARENTE GONTROVÉRSIA}

A mais antiga especulação sobre os tons musicais na Grécia teve como resultado uma lei da acústica e da física matemática, a proporcionalidade inversa entre a altura do tom e o comprimento de uma corda vibrante, formulada em termos de razões aritméticas. Esse marco inaugural dos pitagóricos inseria-se na concepção pré-socrática da existência de uma ordem intrínseca da natureza, inalcançável pelos sentidos. Mas a ordenação musical possuía uma especificidade, na medida em que podia ser facilmente reproduzida e observada em um instrumento, no caso, uma corda esticada.

No desenrolar da presença do pitagorismo na teoria musical antiga, a abordagem racional expressa pela aritmética impôs-se sobre o empirismo da utilização do cânone, instrumento criado para a verificação das consonâncias. As razões aritmético-musicais pitagóricas fortaleceram a noção de harmonia universal e tornaram-se um grande modelo para a ciência, perpetuando-se ao menos até o início do século XVII.

No entanto, o campo de estudos da antiga harmônica pitagórica é ambíguo, pois no pitagorismo havia uma interpenetração entre ciência e mito. Nas culturas antigas, cada técnica ou utensílio criado pelo longo desenvolvimento das habilidades humanas tinha sua origem relacionada a um mito. Isso acontecia com ferramentas materiais, como o arco e a lira, ou intelectuais, como a escrita e a linguagem. O pitagorismo, ao 
relacionar o som de uma corda pinçada a uma representação matemática, inaugurou as condições para um afastamento da matriz mítica dos instrumentos musicais, mesmo mantendo seus princípios associados a uma metafísica.

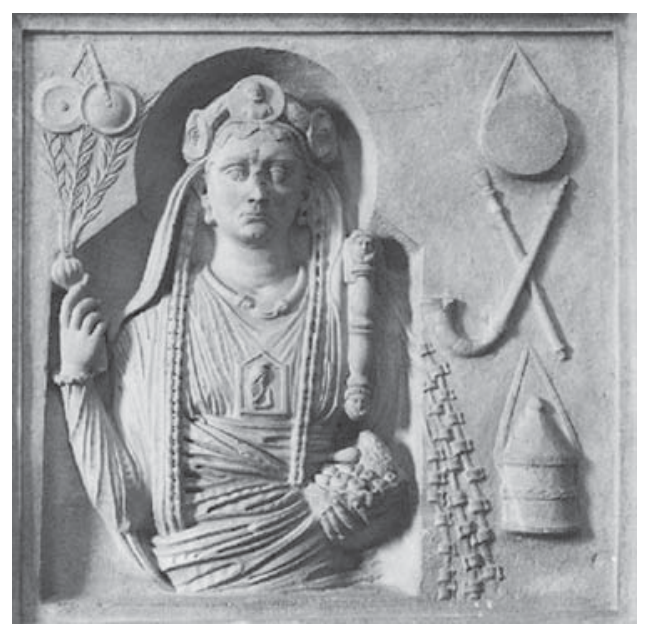

Figura 1. Uma sacerdotisa de Cibele com os instrumentos musicais relacionados a seu culto. Acima, à esquerda, címbalos, à direita, tambor tímpano, logo abaixo, um aulos frígio com um de seus tubos com a campânula feita de chifre, kéras. Relevo romano do século II d.C. (Museu Capitolino, Roma).

Entre os estudiosos, não há consenso a respeito da utilização do cânone, ou monocórdio, pelos pitagóricos. Van der Waerden supõe que o instrumento teria sido criado no século III a.C. por Strato de Lampsacus (cf. Solomon, 1990, p. 7, n. 29). Em obras como Banquete dos sofistas, de Ateneu, do período helenístico, existem referências a músicos virtuoses da época em que floresceu a escola pitagórica no século vi a.C.; tais referências mostram que, ao mesmo tempo que esses músicos se dedicaram à construção de instrumentos, também especularam a respeito da natureza do som. Um deles foi Epígono de Sycion. O filósofo peripatético Aristóxeno de Tarento, do século iv a.C., referiu-se criticamente a Epígono por ele ter defendido, junto com Lasos de Hermíone, que o tom musical possuía largura (cf. Aristóxeno, 1954, p. 7). Epígono foi o construtor de uma harpa de 4.0 cordas, que ele tocava sem plectro, com os dedos diretamente nas cordas e em pé: o epigóneon (cf. Mathiesen, 1999, p. 270). Poderíamos inferir que o epigóneon foi criado em uma antiga oficina grega a partir de investigações acústicas que teriam como objetivo a ampliação dos recursos expressivos do instrumento e, vice-versa, quando o caráter lúdico da ressonância do instrumento mostrou-se propício às especulações acerca do som. Se foram feitas investigações com instrumentos policordes, não vemos porque não seriam com um monocórdio. 


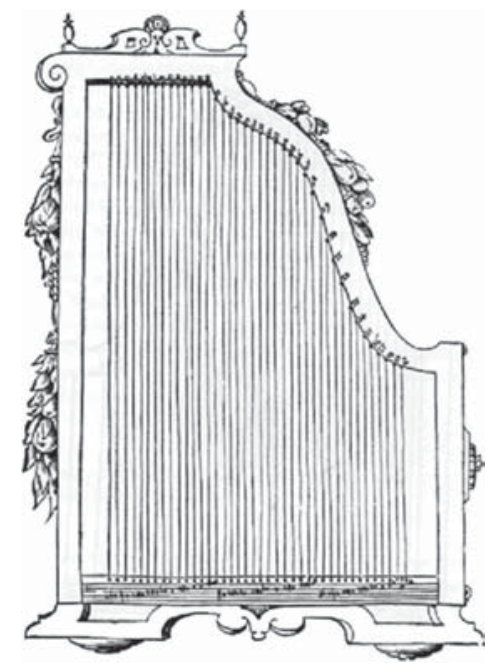

Figura 2. Epigóneon de 40 cordas, instrumento da classe dos psaltérios, cordófonos que eram tocados com os dedos diretamente nas cordas. Essa gravura está reproduzida na obra Dialogo della musica antica e della moderna de Vincenzo Galilei (c. 1520-1591), publicada em $1581 \mathrm{em}$ Florença. $\mathrm{O}$ instrumento aparece no capítulo dedicado à questão das afinações e Vincenzo conclui que pelo número de cordas e pela forma de tocar, utilizando os dedos diretamente nas cordas, seu criador, Epígono de Ambracia, devia afiná-las em consonâncias.

Aristóxeno criticou o uso de instrumentos musicais para a investigação da harmônica, cujo campo ele se dedicou a delimitar rigorosamente. Na sua concepção, não haveria necessidade de instrumentos para fazer verificações, pois “não há erro maior e mais absurdo que fundamentar em um instrumento a natureza da harmonia (

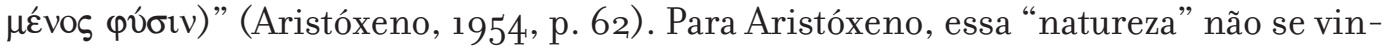
culava às propriedades físicas do som; o tarentino não se interessava nem pela explicação matemática das consonâncias, nem pela explicação acústica. Seu intuito era investigar os tons tal como organizados dentro do sistema musical grego. A harmônica de Aristóxeno estava relacionada à natureza da techne, como definida por Aristóteles no Livro 2 da Física, quando ele fala das duas acepções do termo natureza.

Este então é um modo de falar da physis: como a matéria subjacente (hyle) a cada princípio de movimento e mudança. Outro modo é segundo a forma e a espécie, tal como chamamos de techne aquilo que é de acordo com a techne e os artefatos técnicos; e chamamos de physis aquilo que existe de acordo com a physis e são físicos (Aristóteles, 1996, 2, 193a, 28-34).

O artefato técnico, na obra de Aristóxeno, é a própria música e seus constituintes, tal como se apresentam à escuta (akouh) e são avaliados pela inteligência (dianoia). A construção da ciência harmônica, que ele chama de melos epistheme, passa pela identificação de um conjunto de sons estáveis e organizados do modo como é para Aristóteles a condição do discurso científico. "A aquisição inicial do conhecimento não ocorre pelo vir a ser; pois, de acordo conosco, a razão conhece e pensa por meio do repouso e da 
imobilidade" (Aristóteles, 1996, 7, 3, 247b 10-13; cf. Bélis, 1986). Por serem instáveis na geração dos tons, os instrumentos não poderiam ser confiáveis. ${ }^{3} \mathrm{O}$ tarentino propõe uma aproximação do músico com o carpinteiro, e o afasta do geômetra.

É necessário acostumar-se a julgar cada coisa com precisão; de fato, não podemos dizer, como se faz a propósito das figuras geométricas: 'seja esta linha reta'; não! Devemos abandonar esse hábito ao falarmos dos intervalos. Pois o geômetra não faz uso da faculdade da sensação e nem acostuma a sua visão a julgar bem ou mal à reta, ao círculo ou a outra destas figuras, isto sendo mais da competência do carpinteiro, do que trabalha no torno, ou outros técnicos que se exercitam nessas coisas (Aristóxeno, 1954, p. 48).

O historiador da harmônica grega David Creese detecta uma contradição nessa passagem, pois, em outros momentos, Aristóxeno defende que os músicos deveriam treinar a percepção sem se basear em instrumentos, mas, na passagem citada, seu relacionamento com os instrumentos deve ser como a do carpinteiro (cf. Creese, 2012, p. 62-3). Greese avança mostrando que na obra aristoxeniana a proposta de um procedimento de medição do intervalo de quarta por outros intervalos menores não poderia ser feita sem a mediação de um instrumento, apesar de Aristóxeno não mencioná-lo (cf. p. 53-4). Na verdade, Aristóxeno trata a harmônica como uma ciência natural, mas não deixa claro em sua obra o lugar do saber produtivo aristotélico, que equivale a uma técnica, na medida em que produz ou alcança determinados objetivos seguindo certas regras. A medicina e a arquitetura seriam alguns exemplos. Por que não a música?

Assim como as razões numéricas pitagóricas, a natureza do melos aristoxeniano é uma construção racional. Apesar de serem concepções distintas, ambas integram o mesmo quadro geral que tem como ponto de referência a natureza para elaborar os seus princípios. De um lado, a natureza da physis e, de outro, a da techne. Aristóxeno relacionou as propriedades do som musical à percepção humana, já os pitagóricos buscaram os padrões intrínsecos de sua estrutura. Em ambas, as consonâncias são o elemento unificador dos sistemas.

A controvérsia epistemológica principal, entre princípios pitagóricos e aristoxenianos, ocorre no plano da sistematização da harmônica. Contudo, consideramos que o pensamento sobre a ciência e a arte em geral, e a música em especial, não está

3 A questão da instabilidade dos instrumentos suscita a pergunta a respeito de onde partiriam tons realmente confiáveis. Se a resposta for a voz humana, poderemos observar aqui a origem de um dos focos de debate que aflorará no Renascimento acerca da distinção entre música natural, produzida pela voz humana, e música artificial, gerada pelos instrumentos. 
desvinculado das técnicas de seu tempo, sendo necessário incorporar elementos advindos da prática musical, da construção de instrumentos e mesmo das circunstâncias de performance para a sua compreensão. Essa posição está em acordo com a de Max Weber, para o qual "as relações entre a ratio musical e a vida musical pertencem às relações variadas de tensão historicamente mais importantes da música” (1995, p. 134-5).

No período em que viveu Aristóxeno, a música e os instrumentos gregos já apresentavam um grau de desenvolvimento razoável e os intérpretes exibiam performances sofisticadas. A sociedade na qual se desenrolava a complexidade dessa música solicitava novas formulações sobre seus efeitos, assim como a respeito das afinações dos instrumentos que a executavam. Nesse contexto, a geometria torna-se o modelo preferido de ciência para a solução de problemas que não haviam sido resolvidos pela aritmética. Aristóxeno irá definir os intervalos musicais em termos de distâncias ou grandezas, ao invés de razões aritméticas. Para Crocker,

\section{(...) existia uma relação muito profunda entre Aristóxeno e a nova geometria, que estava no desenho de um novo tipo de teoria musical que, tal como a nova geome- tria, lidava com intervalos sem referência a números ou razões (1966, p. 99).}

Para Aristóxeno, um intervalo de quinta não é representado pela razão 3:2, mas como 3 tons e meio. Os tons que compõem um intervalo são comparados pela distância em termos geométricos, tal como dois pontos em uma reta. Isso fará que o intervalo de meio-tom, proscrito pela aritmética pitagórica, torne-se perfeitamente viável, desde que percebido.

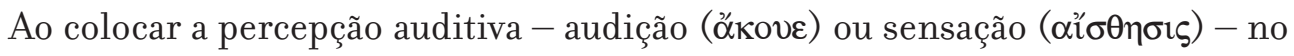
centro da sua harmônica, Aristóxeno refuta facilmente argumentos pitagóricos, em especial quando esses estavam fundamentados na simbologia numérica. Um exemplo disso é a sua definição da propriedade da oitava, que contesta a suposição pitagórica da relação entre as consonâncias e as razões compostas apenas com os quatro primeiros números inteiros. Novamente invoco Max Weber para a explicação da propriedade da oitava, que ele chama de "identidade em outro grau",

(...) o acompanhamento de vozes em oitavas (vozes de homens e vozes de meninos ou mulheres) é um fenômeno universalmente difundido, tendo sido familiar também para a Antiguidade. A oitava, ao que parece, é sentida, por toda a parte onde é encontrada, como identidade em outro grau (1995, p. 105).

Essa propriedade, para Aristóxeno, faz que qualquer intervalo consonante, no qual são acrescentadas uma ou duas oitavas, torne-se consonante também. Desse modo, 
a quarta+oitava ( $11^{\mathrm{a}}$ ) era incluída entre as consonâncias. Para os pitagóricos, esse intervalo não podia ser considerado consonante, pois sua razão, 8:3, extrapolava a rigorosa limitação de utilizar apenas os 4 primeiros números para as razões das consonâncias.

De acordo com Aristóxeno, os argumentos dos pitagóricos eram confusos e contrários ao que se apresenta aos ouvidos. Desse modo, não se contesta o modelo de harmonia universal diretamente, a teoria aristoxeniana desequilibrou alguns de seus pilares especificamente no campo da música, pois argumenta que a classificação dos intervalos em consonâncias ou dissonâncias não depende da aritmética.

Gibson observa a respeito da teoria aristoxeniana que "sua ambição de confiar nos primeiros princípios e na demonstração a fim de estabelecer os teoremas da ciência são minados pela própria natureza da música" (2005, p. 73 ). Essa "natureza" da música implicaria reconhecer a tensão existente entre aquilo que é universal, ou natural, nela - os sons e seus harmônicos - e o que é cultural - os sistemas musicais. Ou seja, ao final, a estabilidade do sistema musical grego, que Aristóxeno buscou organizar, era bastante relativa.

\section{Física E MATEMÁtiGa NA HARMÔNIGA HELENística}

No período helenístico, a rígida concepção pitagórica da harmônica é aprofundada. Contudo, estabelece-se um diálogo com as experimentações acústicas que avançavam e que poderiam colocar em xeque o modelo de ciência pitagórica amplamente utilizado. Isso é percebido na obra Divisão do cânone, de autoria incerta, referida como sendo do pseudo-Euclides. Nela, as demonstrações das consonâncias são feitas no monocórdio, ou cânone, e os tons são definidos como uma sequência de movimentos, que têm partes. Na medida em que não há instrumentos técnicos capazes de perceber essas partes dos movimentos, a obra sustenta que distender ou tencionar as cordas para afinálas equivaleria a subtrair ou somar movimentos (cf. Pseudo-Euclides, 1991, p. 115), insistindo no modelo aritmético.

A Divisão do cânone revela uma tendência da época em trazer os argumentos para um campo quantitativo, apresentando experimentos em instrumentos, seja de aprendizado, como o cânone, seja de performance, como a cítara e o aulos. Lloyd chamou a atenção para os campos da antiga ciência grega em que os termos técnicos cunhados oferecem definições bastante claras, por exemplo, na anatomia, na zoologia, na astronomia e na harmônica (1987, p. 206). Em especial, na astronomia e na harmônica havia um aparato mínimo de instrumentos criados para propiciar cálculos e medições. Se é possível aferir o grau de avanço técnico de uma ciência a partir de seu aparato técnico-linguístico, 
a harmônica grega foi, de fato, um campo de extrema sofisticação e a sua terminologia tem origem basicamente nos instrumentos musicais (cf. Gusmão, 2010, p. 20-1).

Outra vertente da especulação musical do período helenístico situa-se em uma direção diversa à do Pseudo-Euclides e que já havia sido explorada por autores mais antigos, como Teofrasto de Eresus (372-288 a.C.), aluno de Aristóteles, e com quem Aristóxeno rivalizou na sucessão da direção do Liceu. Parte significativa da obra sobre música de Teofrasto foi perdida, mas ela não foi tão importante para a sistematização e autonomização da harmônica como a obra de Aristóxeno. No entanto, Teofrasto aponta elementos importantes, quando defende que as diferenças tonais da música, apesar de seguirem determinadas leis quantitativas, adviriam também de uma base qualitativa como a intensidade da voz no canto, as dimensões do tubo do aulos e a densidade das cordas (cf. Schueller, 1988, p. 82).

Esse olhar sobre a instância material está presente em um dos mais importantes textos para a história dos instrumentos musicais do período helenístico, conhecido

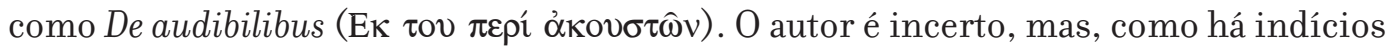
de conexões de suas ideias com as da escola peripatética, a obra costuma ser referida como de autoria do Pseudo-Aristóteles. No tratado, não há explicações aritméticas ou geométricas. Na visão do autor, "os sons permanecem similares em caráter a suas fontes geradoras" (Pseudo-Aristóteles, 1989, p. 106), indicando que as qualidades audíveis relacionam-se às qualidades tangíveis, conclusão bem diferente daquela do modelo matemático e também da harmônica aristoxeniana.

Seu interesse principal é sobre a voz humana, que poderíamos chamar "natural”, na primeira acepção de natureza de Aristóteles mencionada anteriormente. Mas, como na voz é mais difícil observar os mecanismos de produção e transmissão do som, o autor faz analogias com instrumentos musicais, a fim de esclarecer elementos da acústica, ou seja, abordando a música por um viés diferente do das consonâncias e dissonâncias. As discussões estão baseadas em analogias entre a voz humana e os instrumentos musicais, com menções também aos sons da natureza e a máquinas, como as catapultas. Além disso, o autor discute a fisiologia da emissão vocal, as causas das várias modificações nas qualidades perceptíveis do som (distância ou proximidade, brilho, claridade, opacidade, aspereza) e modos de produção do som nos instrumentos.

O tratado descreve as diferentes formas de recipientes envolvidos na produção do som, principiando pelo corpo humano: a boca, a traqueia e o pulmão. Este último, tal como o fole, não pode ser pequeno, denso e duro, se quiser lançar o som a uma longa distância, tal como "as catapultas não podem lançar a grandes distâncias, se suas cordas estiverem rijas" (Pseudo-Aristóteles, 1989, p. 100). 
Outra seção do De audibilibus versa sobre o tratamento que se deve dar aos chifres de animais, keras, os quais podem ser soprados diretamente (tal como a shofar judaica ou o berrante brasileiro) ou encaixados no final de tubos de instrumentos de sopro a fim de ampliar sua capacidade de ressonância. A recomendação é que eles sejam cozidos para que atinjam a ressonância desejada.

Cozinhar os chifres contribui enormemente para a suavidade do som, pois aqueles que foram cozidos têm uma ressonância mais próxima dos vasos de cerâmica, devido a sua resistência e secura produzidas pelo fogo (Pseudo-Aristóteles, 1989, p. 104).

Para o autor, quanto mais reto for o oco do chifre, melhor, pois quando o som se desloca, ele não deve encontrar nenhuma obstrução, senão a ressonância será abafada. Ele ilustra a tese referindo-se à forma de testar os mastros de um navio pelo som.

Quando se bate de um lado do mastro de um navio, a ressonância viaja continuamente até o outro lado, a não ser que a baliza esteja rachada, nesse caso o som avança até certo ponto, se dispersa e desaparece (Pseudo-Aristóteles, 1989, p. 104).

Em outro momento, o escritor faz advertências sobre a qualidade das cordas e também das palhetas dos auloi, com o objetivo de melhorar seus timbres. Para os intérpretes, são fornecidas orientações sobre o sentido das variações de timbres que devem ser obtidas pelos instrumentos, de acordo com o que for exigido pela situação. Como no caso da trombeta salpinx, bastante utilizada em contextos marciais, mas que se for tocada em uma festa deve-se "relaxar a tensão do sopro, para tornar o som o mais suave possível" (Pseudo-Aristóteles, 1989, p. 106).

Em alguns momentos do De audibilibus, se não fosse pelo estilo e pelos nomes dos antigos instrumentos, poderíamos imaginar alguém discorrendo hoje sobre a técnica de modelagem física - técnica de simulação de instrumentos musicais que utiliza um algoritmo para computar o comportamento das formas de onda sonora e reproduzi-lo. Como no exemplo a seguir.

Assim, as cordas torcidas de maneira apertada produzem sons mais duros, tal como os chifres quando cozidos. Se alguém dedilha as cordas violentamente e não suavemente, elas darão uma resposta igual e necessariamente mais violenta. Cordas que não foram muito apertadas e chifres que não foram muito cozidos produzem sons mais suaves e, do mesmo modo, os instrumentos de maiores pro- 
porções. Pois os golpes no ar são mais lentos e suaves devido ao tamanho dos espaços envolvidos, enquanto que aqueles que são produzidos por instrumentos menores são mais duros devido à tensão das cordas. É evidente que o som de um instrumento é mais áspero quando se tange as cordas em um lugar que não seja o meio delas, pois as partes da corda que estão mais próximas do estandarte e das cravelhas apresentam-se sob uma tensão muito maior. Instrumentos feitos de madeira mais macia produzem sons mais suaves, pois os sons, chocandose contra algo macio, não repercutem com a mesma força (Pseudo-Aristóteles, 1989, p. 106).

As objeções de Aristóteles ao pitagorismo referiam-se à metafísica e à astronomia. No que tange às razões numéricas musicais, ele estava de acordo que elas fossem os princípios da ciência da música, como é possível ler na obra Analíticos posteriores.

O que é a consonância? É a razão dos números no agudo e no grave. Por que o agudo harmoniza com o grave? Porque uma razão aritmética situa-se entre os dois (Aristóteles, 1987, 90a19-22).

Assim, os fragmentos do De audibilibus representam uma modificação profunda na abordagem musical. A causa eficiente da música já não está apenas nos números e nas consonâncias, mas em tudo que a compõe. Apesar de a obra ter elementos da escola peripatética, podemos ver nela traços do ceticismo, um dos movimentos filosóficos do período. Essa filiação seria possível se considerássemos a aplicação do ceticismo à música tal como presente na obra de Sexto Empírico, responsável pela escola cética na sua fase final, no século iı d.C. No livro 6 da obra Contra os matemáticos, ele condena o dogmatismo vigente na arte musical, mas deixa claro que seus ataques são contra uma maneira de conceber a música, ou seja, como a ciência da harmônica, "tal como dizemos que Aristóxeno, o filho de Espíndaro, era músico" (Treiler, 1998, p. 95). O filósofo cético preserva, no entanto, o fazer musical, ou seja, "a ciência concernente à experiência instrumental, tal como os auletistas, os psalteristas e as mulheres harpistas" (Treiler, 1998, p. 95). Tanto a postura cética de Sexto Empírico quanto a teoria física do De audibilibus devem igualmente ao epicurismo representado por Lucrécio no século I a.C. No livro 4 da obra De rerum natura, o autor romano descreve aspectos físicos e materiais do som e da voz.

Por fim, no período helenístico surge um novo instrumento musical, o hydraulis, considerado uma invenção do engenheiro alexandrino Ctesibius. É importante ressaltar que esse é o primeiro instrumento da cultura grega cujos princípios não foram revelados dentro de um mito, ele é um mecanismo, uma máquina, criada por um ho- 


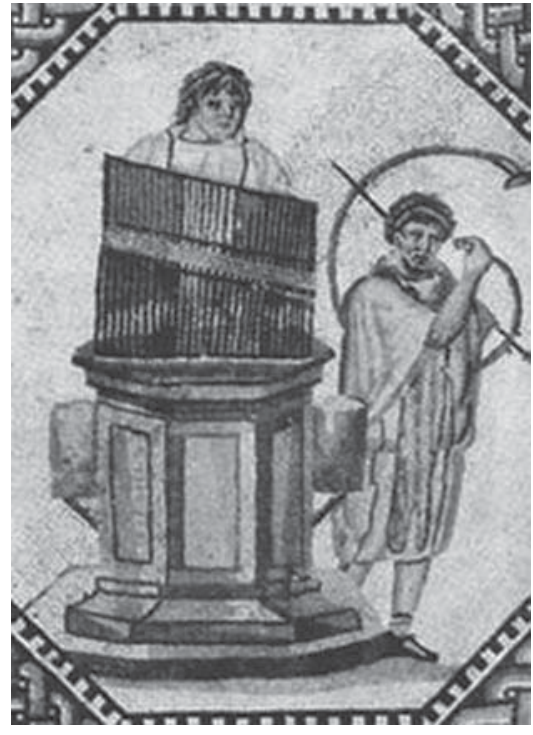

Figura 3. Hydráulis e cornu. Mosaico da vila romana de Nennig, Alemanha, século II d.C. No mundo romano, o hydráulis costumava ser representado ao lado de instrumentos de metal como o cornu ou a tuba.

mem e não por um deus ou semideus. Ctesibius empregou a tecnologia de pressão do ar em diversos dispositivos, tais como o relógio de água, a catapulta pneumática e a bomba com êmbolo e válvula. O próprio hydraulis pode ter sido criado para demonstração de princípios da hidráulica, mas a transferência dessa tecnologia para um instrumento musical representa um dos saltos tecnológicos mais significativos da música da Antiguidade.

\section{A teoria harmônica de Ptolomeu}

Ptolomeu, logo no início do tratado de harmônica, anuncia e busca justificar o conjunto de procedimentos que os praticantes da ciência devem seguir se quiserem produzir bons resultados. Uma comparação com a astronomia é apresentada:

Preservar de todo modo as hipóteses racionais obtidas no cânone, as quais não devem de maneira nenhuma entrar em conflito com as percepções da maioria das pessoas, tal como o propósito do astrônomo é preservar as hipóteses dos movimentos celestes de acordo com seus cursos cuidadosamente observados, sendo esses postulados obtidos a partir do fenômeno real e evidente, mas descobrindo cada coisa o mais precisamente possível por meio da razão (Ptolomeu, 2000, p. ₹).

Percebe-se que o que está em jogo é a preservação daquilo que é percebido como fenômeno e não a redução de uma aparente irregularidade a uma regularidade que estaria subjacente. Mas, ao mesmo tempo, para Ptolomeu, como já dissemos, é crucial utilizar os cálculos para obter maior precisão e, para isso, alguma simplificação será necessária. Como chama a atenção Lloyd,

um elemento de simplificação e idealização está presente em toda ciência, pois é apenas ignorando algumas características do que está dado que as relações subjacentes que governam os fenômenos podem ser reveladas (Lloyd, 1987, p. 285). 
Mas Ptolomeu transforma a própria harmônica em um instrumento de reflexão sobre os métodos e procedimentos científicos, combinando de maneira complexa razão e sensação. Elas são as duas formas de apreensão da harmônica, mas não atuam do mesmo modo, pois “a percepção descobre o que é aproximado e aceita o que é exato, ao passo que a razão aceita o que é aproximado e descobre o que é exato" (Ptolomeu, 2000, p. 3). Ptolomeu critica os pitagóricos e os aristoxenianos, deixando claro para o leitor que não quer ser associado a nenhuma dessas correntes.

À luz dessas demonstrações, deve-se criticar os pitagóricos, não por sua descoberta das razões das consonâncias, pois eles estão corretos, mas onde eles falharam em atingir seu objetivo. Por outro lado, deve-se criticar os aristoxenianos, pois eles não concordam que aquelas razões são evidentes e, quando as rejeitam, não procuram outras mais seguras, apesar de sua promessa quanto a um estudo teórico da música (Ptolomeu, 2000, p.28).

Ptolomeu contempla as duas vias, pitagórica e aristoxeniana, na sua Harmônica, avançando a passos firmes na versão geométrica, embora mantendo o conceito de harmonia dos pitagóricos, buscando observar o que havia de melhor nas duas vertentes. Alguns autores, como Crocker (1966, p. 96), consideram que foi Ptolomeu em sua Harmônica que fixou o aristoxenianismo no campo sensorial, sendo essa concepção injustamente perpetuada nos períodos subsequentes. No entanto, considero mais provável que ele apenas tenha feito a referência aos nomes das escolas tal como eram utilizados em seu tempo. Sem contar que na obra ptolomaica a teoria harmônica de Aristóxeno contribui para a problematização do pitagorismo e vice-versa.

Além disso, Ptolomeu amplia o âmbito das relações tonais para o da física natural. A tarefa da harmônica ptolomaica será identificar os intervalos e as estruturas das escalas e investigar os princípios dessas distinções e o ponto de partida é o exame da qualidade do grave e do agudo no som em geral. ${ }^{4}$ Não obstante, sua análise da diferença entre agudo e grave discute a forma de produção do som, "o que é mais denso e mais fino produz sons mais agudos, o que é mais esparso e mais grosso produz sons mais graves" (Ptolomeu, 2000, p. 12). Apesar de ser, ao final, o parâmetro da altura que vai interessar ao filósofo para fundamentar a sua teoria da harmonia, até chegar a ela, ele discorre sobre a potência, a ressonância e a distância do som.

A proposta ptolomaica de afinação é central e surge da sua concepção de harmônica e dos critérios que considera que devam ser adotados por quem a investiga, ou seja,

4. "O som é uma tensão contínua do ar que circunda as coisas e é levado para dentro delas produzindo uma perturbação e, portanto, de acordo com o grau de tensão, o som torna-se mais grave ou mais agudo” (Ptolomeu, 2000, p. 12). 
um entrelaçamento entre a razão e a percepção. Se a audição e a razão são critérios de avaliação da harmônica, elas não funcionam da mesma maneira. Ptolomeu divide o território. A audição é concernente à matéria (hyle) e ao pathos, aqui entendido como o pathos do ar. E a razão refere-se à forma (eidos) e à causa (aition) (cf. Ptolomeu, 2000, p. 3-5) .

Ptolomeu apresenta a lista mais completa até então das diversas propostas de afinação como a de Arquitas, Eratóstenes, Aristóxeno e Dídimos. Contudo, Ptolomeu não faz apenas um inventário de teorias, pois, seguindo sua metodologia, propõe suas próprias afinações a partir da observação cuidadosa dos instrumentos teóricos e práticos e da performance dos citaristas de seu tempo. Um dos legados ptolomaicos mais importantes é o da afinação sintônica diatônica, que ficou conhecida como afinação justa. Nela, o intervalo de terça é construído pela razão 5:4, que é uma razão superparticular, mas que ficava fora do âmbito da tetraktys pitagórica. A afinação pitagórica tinha uma preferência pela quinta justa, razão 3:2, por meio da qual eram marcadas todas as outras notas no monocórdio. A inclusão da terça como base da afinação abria uma janela para a gradual dissipação da rígida distinção entre consonância e dissonância.

Ptolomeu faz uma classificação das consonâncias em gradações. Ele considera consonante o intervalo de quarta mais oitava $\left(11^{\mathrm{a}}\right)$, tal como Aristóxeno, e em desacordo com os pitagóricos. As duas primeiras classes ptolomaicas de consonâncias são homófonas - 2:1 (oitava) e 4:1 (dupla oitava) - e sinfônicas - 3:2 (quinta) e 4:3 (quarta), esta última classe com suas combinações com os homófonos, ou seja, a $11^{\mathrm{a}}(8: 3)$ e a $12^{\mathrm{a}}$ (3:1). Ptolomeu argumenta a respeito da inclusão da $11^{\mathrm{a}}$ entre as consonâncias:

que essa razão [8:3] não seja epimórica nem múltipla não nos trará embaraço, na medida em que não adotamos nenhuma hipótese desse tipo anteriormente (2000, p. 23).

Lembremos que, para os pitagóricos, além de ser múltiplo ou superparticular, para que um intervalo fizesse parte do rol das consonâncias, seria necessário ainda participar das razões formadas pelos números 1, 2, 3 e 4, formadores da tetraktys; tanto o 5 quanto o 8 escapam dessa determinação.

A terceira classe de intervalos consonantes ptolomaicos é a emélica, que inclui "o tom inteiro e quaisquer outros que perfaçam a menor das consonâncias, de modo que aquelas sejam razões menores que a sesquitércia [4:3]" (Ptolomeu, 2000, p. 23). Assim, a razão 5:4, está entre as consonâncias emélicas. Essa insinuação da terça maior como consonância levará a desenvolvimentos significativos na prática musical. Contudo, ela só será substancialmente retomada no século xv, já no contexto da música polifônica, por Bartolomeo Ramos de Pareja, em seu livro Musica practica, publicado em Bolonha em 1482, e, no século xvi, por Gioseffo Zarlino de maneira mais completa. 


\section{Os INSTRUMENTOS DA HARMÔNICA PTOLOMAICA}

Na história das razões numéricas, a descoberta de Pitágoras foi levada cada vez mais para um contexto quantitativo, buscando responder aos avanços da ciência acústica. Serão retomadas narrativas como a de Xenócrates, do século iv a.C., da famosa história dos martelos de Pitágoras, reproduzida pelo neopitagórico Nicômaco de Gerasa (60-120 d.C.) em seu Manual de harmônica, e inúmeras vezes durante a Idade Média e início da modernidade. No livro Theorica musicae de Franchino Gaffurio, editado em 1492, Pitágoras é representado em diversas situações de “experimentação" das consonâncias. Os experimentos com os martelos, com copos d'água e outros se mostraram equivocados e, talvez, nunca tenham sido feitos, mas o objetivo da narrativa foi alcançado, ou seja, apresentar Pitágoras fazendo experiências acústicas em uma antiga forja.

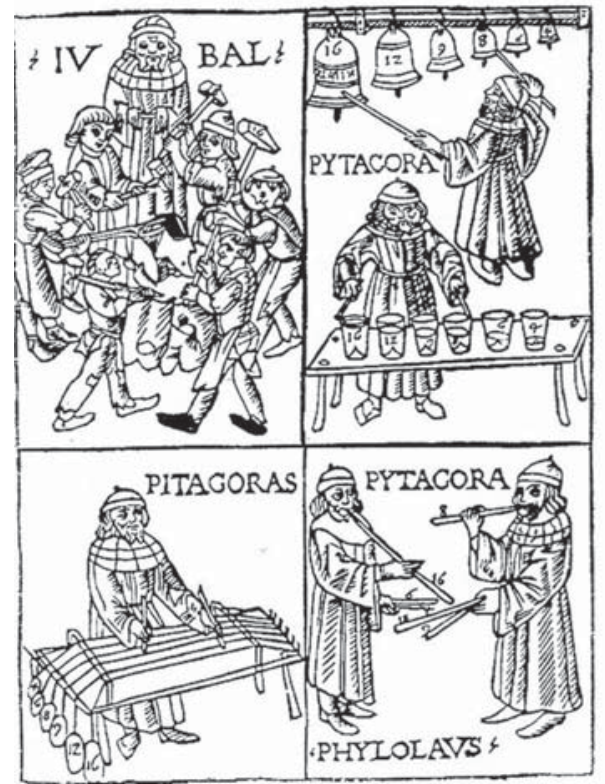

Figura 4. Os experimentos de Pitágoras representados em gravura da obra publicada em 1492, Theorica musicae, do influente teórico e músico italiano Franchino Gaffurio (1451-1522).

Os instrumentos e sua manipulação prática desempenham um papel fundamental na harmônica ptolomaica. Logo no primeiro livro, Ptolomeu se diz descontente com o cânone como aparato de investigação e adentra aspectos da construção de instrumentos e da performance da época. Mas isso é bem diferente da tentativa de Nicômaco de inserir à força as razões numéricas pitagóricas um quadro pretensamente experimental. Ele propõe instrumentos para a investigação dos intervalos musicais, 
iniciando pela verificação empírica em dois instrumentos de sopros, no aulos e na syrinx, percebendo que não é possível utilizar esses instrumentos de sopros para cumprir seu objetivo. No mesmo trecho em que trata disso na Harmônica, desqualifica os experimentos pitagóricos com os martelos e outros artefatos.

Devemos desistir de examinar nosso assunto por meio do aulos e da syrinx ou pesos presos a cordas, pois tais demonstrações não nos podem trazer conclusões precisas. Em vez disso, elas convidam à calúnia em suas empreitadas, pois os auloi e as syringes são difíceis de examinar, e mesmo se suas inconsistências fossem corrigidas, seus limites, que são necessários para a comparação dos comprimentos, ainda seriam estabelecidos apenas de maneira vaga. Além disso, na maioria dos instrumentos de sopro há alguma irregularidade no fluxo de ar. Com pesos presos às cordas, elas não se mantêm inalteradas uma em relação às outras. Ademais, é difícil fazer isso com cada corda em relação a si mesma, pois as razões dos pesos não serão adequadas a concordar com os sons produzidos, visto que, com a mesma tensão, cordas mais grossas ou mais finas produzem notas mais agudas (Ptolomeu, 2000, p. 24,-5).

Como vemos, Ptolomeu conversa com a tradição, mas rejeita algumas vias de investigação.

Dificuldades parecidas ocorrem quando sons produzidos por percussão, sons que alguém observe produzidos por martelos de peso desigual ou discos e por recipientes vazios e cheios, pois é, de fato, uma tarefa difícil observar em todos eles constância no que diz respeito à matéria e à forma (Ptolomeu, 2000, p. 25).

No caso dos discos, ele se refere aqui à experiência de Hipaso de Metaponte, do século v a.G., que teria feito experimentos com discos de bronze de mesmo diâmetro, cuja espessura estava na mesma relação das razões das consonâncias; percutindo os discos, era possível ouvir as consonâncias. De acordo com Burkert,

(...) a experiência é fisicamente correta, pois para discos que podem vibrar livremente, o número de vibrações é diretamente proporcional a sua espessura. Portanto, é possível confiar que Hipaso conhecia e tenha experimentado as razões numéricas das consonâncias (apud Szabó, 1977, p. 122).

Ptolomeu remete-se também a expressões presentes no livro de Nicômaco de Gerasa (cf. 1994), que é de uma geração imediatamente anterior a sua, e que Ptolomeu, 
em alguns momentos, parece atacar. No caso do cânone, reaparece a imagem da necessidade dos ouvidos serem dotados de ferramentas apropriadas, tal como os olhos utilizam a régua e o compasso. Mas o argumento é diferente.

Para os ouvidos, similarmente, que ao lado dos olhos são os maiores mensageiros da parte racional e teórica da alma, também há necessidade de alguma abordagem racional para lidar com coisas cuja natureza eles [olhos e ouvidos] não são capazes de julgar com precisão (...). O instrumento desse tipo de abordagem é chamado de cânone harmônico, um termo que vem da sua capacidade de medir e fornecer medições onde a percepção sensível é inadequada para revelar a verdade (Ptolomeu, 2000, p. 6-7).

Ou seja, para que haja uma representação precisa, são necessários aparatos técnicos específicos. Ptolomeu propõe a construção de alguns deles. Na sua Harmônica, seis são os capítulos dedicados a descrições detalhadas de suas elaborações, tanto do ponto de vista de suas propriedades quanto de seu design.

Sabe-se que o astrolábio armilar foi o instrumento mais sofisticado que o astrônomo utilizou para fazer suas medições astronômicas. Segundo Lloyd (cf. 1990, p. 139), no livro 5 da Syntaxis mathematica, Ptolomeu explica como descreveu a posição da Lua com o astrolábio, instrumento que já existia antes dele, mas do qual ele diz ter construído o seu próprio exemplar. Parece-nos, então, que Ptolomeu tinha uma oficina de trabalho ou dispunha de alguém que fizesse esses instrumentos para ele. Quais técnicas de construção estariam disponíveis a Ptolomeu? A sua descrição da construção do cânone é de alguém que, se não construiu o instrumento de fato, acompanhou de muito perto a execução. Por exemplo, nos experimentos no monocórdio, ele descreve, por meio de um desenho, de que modo o cavalete para criar as variações tonais fará com que a corda suba um pouco, originando uma pequena curva, o que modificará a medição do comprimento da corda. Ele não parece estar falando de uma corda ideal, pois dá detalhes da colocação desses cavaletes que devem ser "iguais, formando da melhor maneira possível superfícies esféricas por debaixo das cordas" (Ptolomeu, 2000, p. 26).

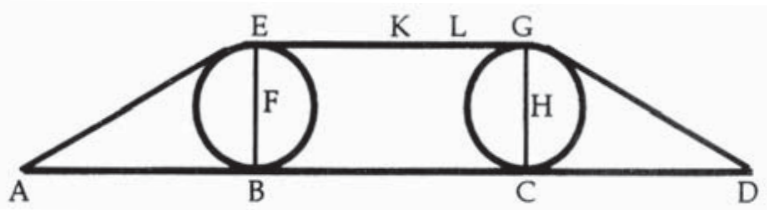

Figura 5. Marcação de pontos precisos no cânone.

Os pontos $\mathrm{K} \mathrm{e} \mathrm{L}$ correspondem à marcação da quarta $\mathrm{e}$ da quinta respectivamente. 
Para um matemático como Ptolomeu, a determinação precisa dos pontos no cânone é fundamental, pois, como diz Barker, a respeito da colocação precisa dos cavaletes,

(...) eles evidentemente têm a vantagem, da perspectiva de um matemático, de que a parte da corda que toca a superfície em um único ponto, bem definido, como EG, se estendida em ambas as direções como uma linha reta, seja uma tangente aos círculos EFB e GHC (Barker, 2000, p. 197).

Desse modo, é possível checar as relações harmônicas das consonâncias e visualizá-las. Para outros fins, Ptolomeu propõe um instrumento de oito cordas, todas afinadas em uníssono, ou seja, em uma mesma altura, grau ou tensão. Em seguida, ele divide as cordas com cavaletes para produzir diferentes comprimentos de acordo com as relações que serão estudadas. Com o cânone de oito cordas será possível tocar todas as notas da oitava em várias construções diferentes de escalas. Ele sabe da impossibilidade, em seu tempo, de conseguir oito cordas de espessura igual. Mas isso não será necessário para o experimento, pois, para ele, é a tensão que deve ser igual.

Existem três razões para a diferença entre o agudo e o grave - a densidade, o diâmetro e o comprimento das cordas. Os sons mais agudos resultam de uma corda mais densa, mais fina e mais curta; a tensão faz aqui o papel da densidade, pois ela cria tensão e dificulta também o que poderia ser similar a uma corda mais curta (Ptolomeu, 2000, p. 37-8).

Como diz Barker, "a descrição de Ptolomeu do cânone é certamente adequada para oferecer a um luthier toda a informação necessária para construir um e colocá-lo em uso" (Barker, 2000, p. 203).

No primeiro livro da Harmônica, particularmente no oitavo capítulo, intitulado "De que modo as razões das consonâncias serão demonstradas fielmente no monocórdio cânone", o cientista parte das razões matemáticas para o instrumento. No livro 2, o caminho é inverso, "como as razões das consonâncias nos gêneros conhecidos devem ser reconhecidas também pelos sentidos".

Examinemos agora de uma outra forma aqueles gêneros costumeiros e facilmente apreciados pelo ouvido. Não da mesma forma como fizemos até agora, produzindo as diferenças das razões e depois testando-as no cânone, confrontando com a evidência que surge aos ouvidos, mas da maneira oposta, primeiro achando as 
afinações a partir da audição e depois demonstrando as razões delas. Assumindo os intervalos reais utilizados pelos citaristas e demonstrando as razões que os descrevem (Ptolomeu, 2000, p. 60).

Aqui, Ptolomeu já não considera o cânone, monocorde ou policorde, adequado como instrumento musical, pois a afinação é alcançada pelo deslizar sucessivo desses cavaletes pela corda e

se a estrutura está bem fixada e o cavalete move-se lentamente, as notas podem ser comparadas razoavelmente bem, mas se ele tiver de ser movido mais rapidamente, de acordo com a progressão da melodia ou do ritmo, o resultado não será similar (Ptolomeu, 2000, p. 93).

É necessário utilizar um instrumento advindo da prática musical como a cítara, pois no cânone

as mãos afinam e tocam o instrumento separadamente e, desse modo, somos desprovidos da mais bela das técnicas de tocar um instrumento como o trilo, ziguezagues para cima e para baixo, empurrar as cordas e tocar em saltos separados, entre outros (Ptolomeu, 2000, p. 94).

Em alguns trechos, Ptolomeu parece estar utilizando o princípio da continuidade (sunexéia) de Aristóxeno, que propõe que a avaliação do intervalo deve ocorrer no interior da escala (cf. Bélis, 1986, p. 139-46), mas parece ir além, pois investiga os intervalos em melodias e afinações que eram utilizadas na prática dos citaristas de seu tempo. Para ele, as relações musicais "erradas" são mais fáceis de ser reconhecidas nas melodias do que em uma escala. Como sublinha Barker,

nenhum outro autor grego de harmônica matemática, que eu saiba, mostrou algum sinal para apreciar a necessidade de apresentar afinações para o ouvido crítico acessar, não como estruturas ou escalas, mas em melodias verdadeiras (2000, p. 206).

Após as experiências com o cânone e a cítara, Ptolomeu apresenta um novo instrumento, o hélicon (cf. Ptolomeu, 2000, p. 66-7). Nele, as médias harmônica e aritmética serão apresentadas nas suas versões geométricas. 

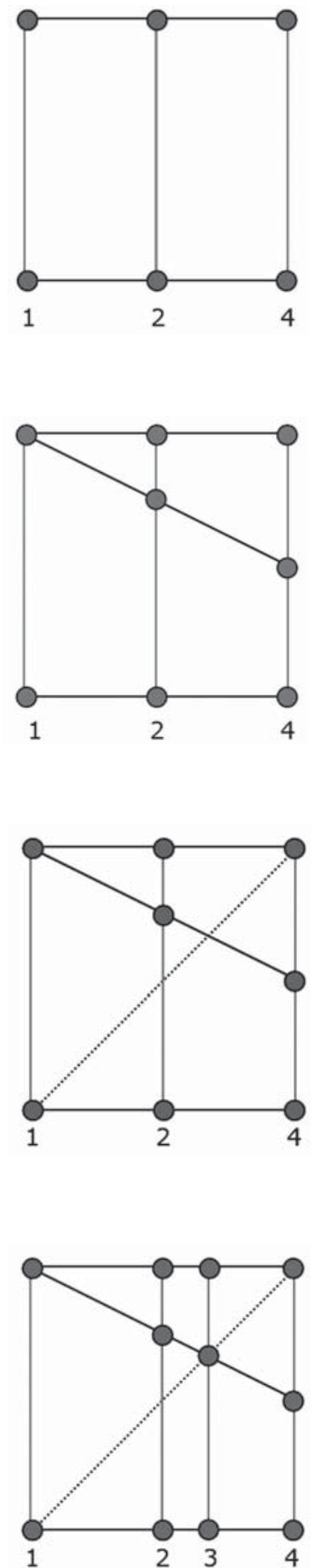

Figura 6. Passo 1 da construção do hélicon.

Figura 7. Passo 2 da construção do hélicon.

Figura 8. Passo 3 da construção do hélicon.

Figura 9. Passo 4 da construção do hélicon. 

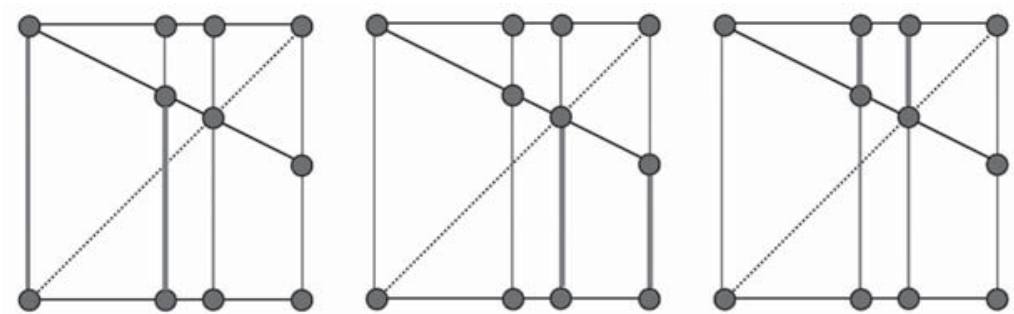

Figura 10. Intervalos musicais demonstrados no hélicon: quartas. A relação entre as cordas em destaque produz o som de intervalos de quarta em três oitavas diferentes, respectivamente: mais grave, média e mais aguda.
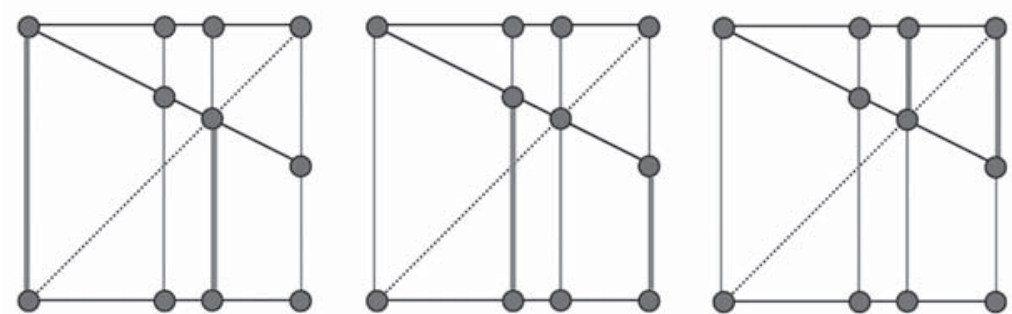

Figura 11. Intervalos musicais demonstrados no hélicon: quintas. A relação entre as cordas em destaque produz o som de intervalos de quinta em três oitavas diferentes, respectivamente: mais grave, média e mais aguda.
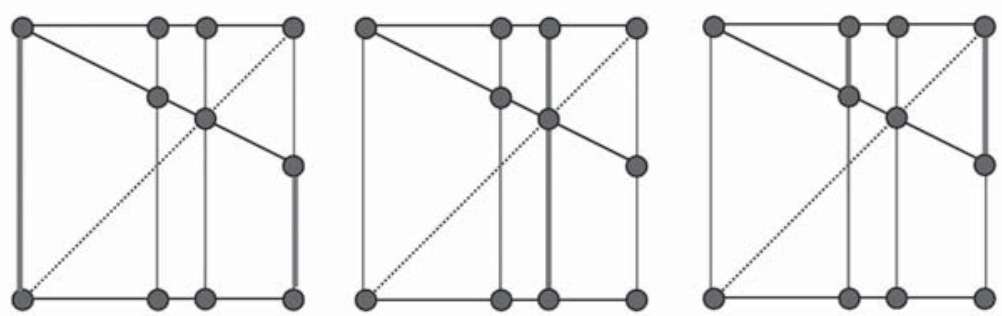

Figura 12. Intervalos musicais demonstrados no hélicon: oitavas. A relação entre as cordas em destaque produz o som de intervalos de oitava em três oitavas diferentes, respectivamente: mais grave, média e mais aguda.

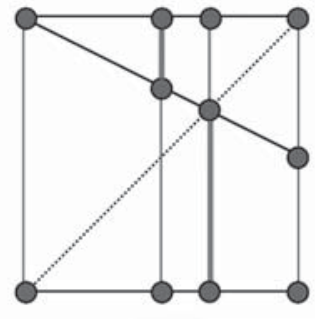

$12 \mathbf{a}$

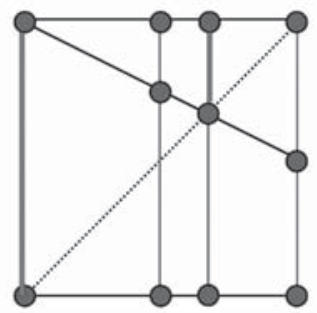

$11 \mathbf{a}$

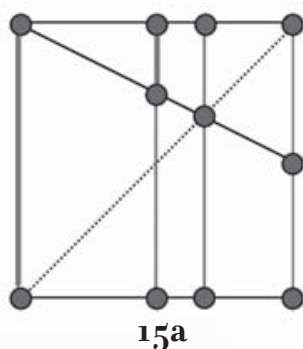

$15 \mathbf{a}$

Figura 13. Intervalos musicais demonstrados no hélicon: 12a, 11a, 15a. A relação entre as cordas em destaque produz o som de intervalos de $12 a$ (quinta+oitava), 11 a (quarta+oitava) e 15 a (dupla oitava), respectivamente. 


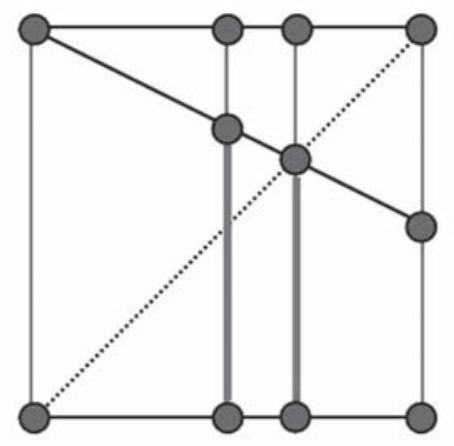

Figura14. Intervalos musicais demonstrados no hélicon: 9:8, tom inteiro. A relação entre as cordas em destaque produz o som do intervalo de um tom inteiro.

O processo de construção do hélicon é simples. Trata-se de um quadrado, de madeira, por exemplo, em que são fixadas quatro cordas. A corda 2 é colocada exatamente no ponto central entre a corda 1 e a corda 4 (ver fig. 6). Em seguida, um suporte é colocado entre o alto da corda 1 e exatamente no meio da corda 4 (ver fig. 7). Uma diagonal puramente teórica é traçada entre o ponto inferior da corda 1 e o alto da corda 4 (ver fig. 8). A corda 3, então, é colocada paralelamente às outras passando exatamente pelo ponto onde o suporte e a diagonal teórica se cruzam (ver fig. 9). Com esse instrumento, os segmentos de cordas podem ser tocados formando as consonâncias e incluindo o tom inteiro. Note-se que, nesse caso, não há necessidade de mover um ou mais cavaletes e, além disso, todo o sistema pode ser visualizado simultaneamente, sem contar o fato de que as cordas podem ser tocadas juntas e não apenas em sequência. Nas figuras 10 a 14, estão em destaque as cordas a serem tangidas para obtenção dos intervalos. Os pontos representam cravelhas de fixação dos segmentos de cordas.

As divisões do hélicon de Ptolomeu têm sua origem no problema clássico da matemática da duplicação do cubo. As soluções apresentadas pelos antigos em geral estavam baseadas em encontrar duas médias proporcionais entre duas grandezas, solução que aparece na Proposição 9 do Livro 6 dos Elementos de Euclides, dadas duas retas encontrar a linha proporcional da metade. Transpondo a solução para o âmbito da harmônica, significa encontrar um som no centro proporcional entre eles.

A chave da construção do hélicon é encontrada na obra Instituições harmônicas de Zarlino, publicada em $155^{8}$. O compositor mostra detalhadamente no Livro 2, capítulo 24, a proposição euclidiana da qual deriva a construção, Proposição 9 do Livro 6 dos Elementos (cf. Zarlino, 2012). No capítulo seguinte, Zarlino oferece outra solução para dividir os intervalos em duas ou mais partes. Aqui ele utiliza o mesolábio, instrumento que teria sido inventado por Arquimedes ou Eratóstenes para encontrar médias proporcionais de maneira mecânica; no caso da harmônica, para demonstrar a possibilidade de uma divisão igual das razões superparticulares. 
O instrumento havia sido reproposto no Renascimento pelo matemático Giorgio Valla (1447-1500) e, depois, pelo organista espanhol Francesco Salinas (1513-1590), que sugere o dispositivo para dividir a oitava em 12 meios tons. De acordo com Salinas, esse método já era utilizado pelos fabricantes de violas (cf. Barbour, 2004, p. 50-1).

O termo mesolábio vem do grego e é formado pelo substantivo mésos (média) e o verbo lambáno (pegar, tomar). O instrumento constituía-se de três taboinhas que corriam uma sobre a outra e, desse modo, permitia a inserção mecânica de médias proporcionais nas cordas. Do vértice superior esquerdo do primeiro quadrado até o vértice inferior esquerdo do terceiro colocava-se um fio ou corda com um peso na extremidade. Dois quadrados possuíam uma diagonal da esquerda para a direita.
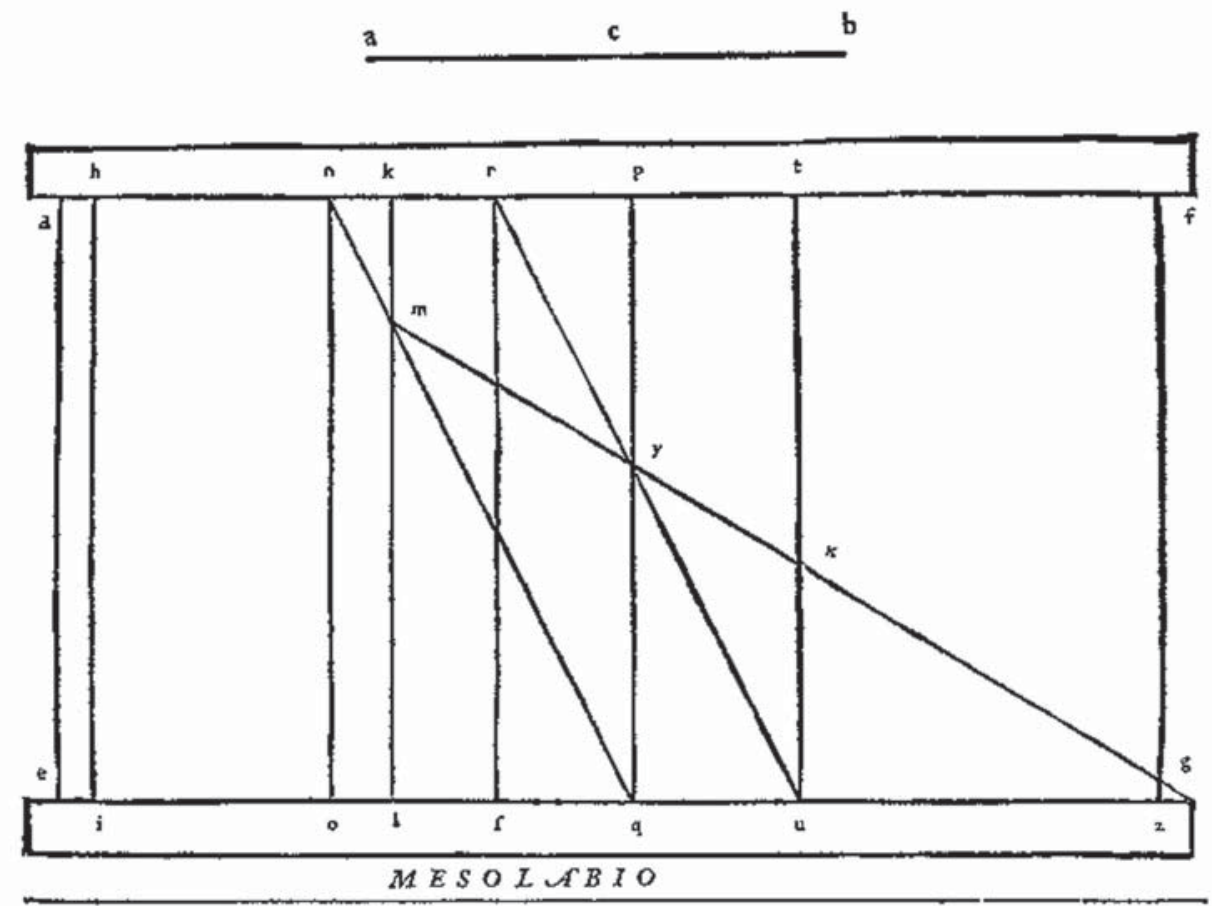

Figura 15. Mesolábio na sua posição inicial. O teórico e compositor italiano Gioseffo Zarlino $\left(15^{17^{-1590}}\right)$ apresentou o mesolábio em 1558 na sua obra Istituzioni armoniche como um artifício mecânico que permitiria visualizar geometricamente a divisão de uma consonância em duas ou mais partes iguais.

O primeiro quadrado à esquerda permanece imóvel, enquanto que os outros dois se movem, formando linhas paralelas nas proporções desejadas. 


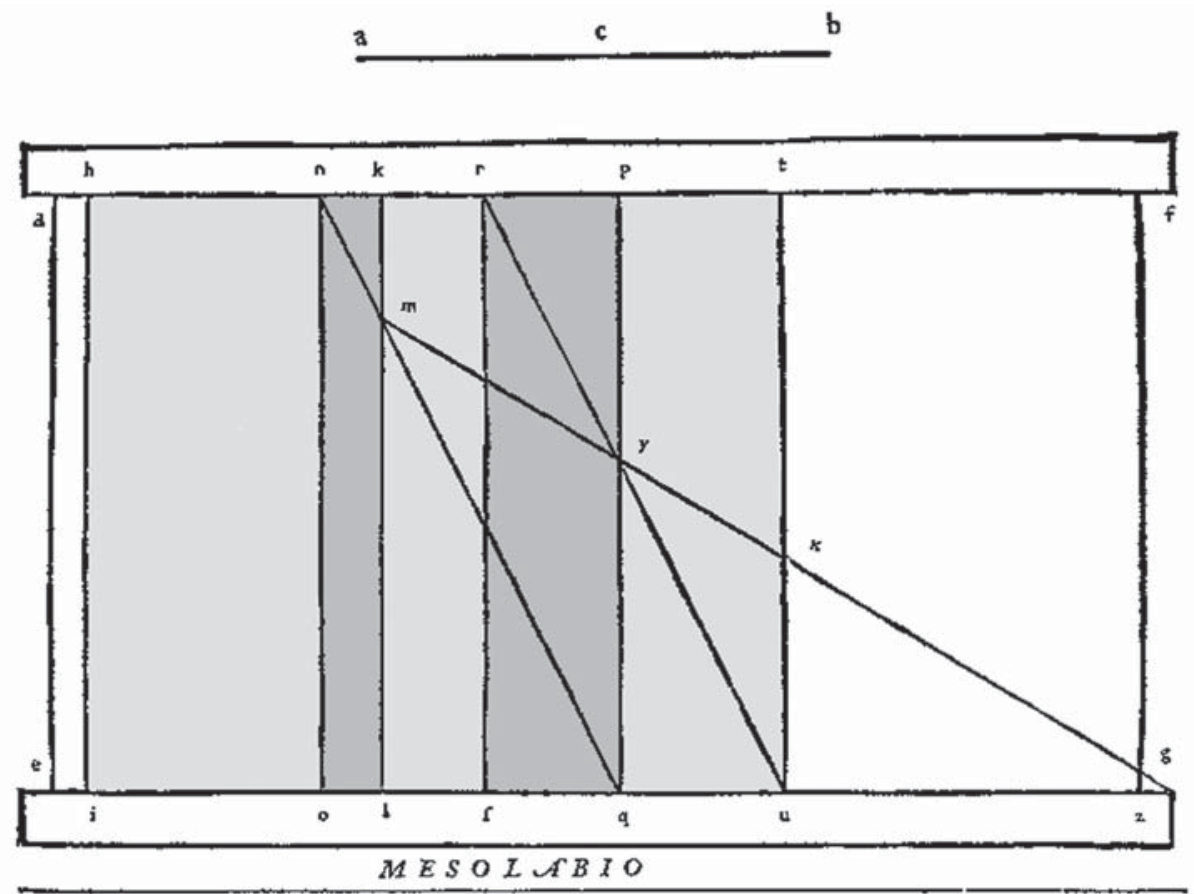

Figura 16. Mesolábio de Zarlino com as tábuas deslocadas. O método geométrico possibilitava a divisão da corda em relação a vários temperamentos da oitava musical, impossível de ser empreendida pela aritmética . Em $\mathbf{1 5}_{\mathbf{5}} \mathbf{8 8}$, na obra Sopplimenti musicali, Zarlino se servirá do mesolábio para calcular a posição do braço do alaúde em relação ao comprimento de sua corda no temperamento igual.

Na obra de Zarlino, as relações geométricas do mesolábio têm como objetivo fundamentar as divisões da corda, buscando demonstrar que "tudo isto é verdadeiro de acordo com os princípios e demonstrações de Euclides” (Zarlino, 2012). Ptolomeu não menciona o mesolábio, mas propõe um instrumento que parece estar baseado nas mesmas proposições euclidianas. Ele terá o deslocamento do suporte em diagonal como o mesolábio, de modo que os intervalos fixos, dentro de uma oitava completa, poderão ser produzidos e, através de um dispositivo lateral, transpostos. O novo instrumento é retangular e possui um centro homotético (E) fora do retângulo, criado a partir da extensão de OP e é pivotante, ou seja, é possível mover o suporte para cima e para baixo de modo a fazer as transposições de tom "enquanto as características do gênero permanecem inalteradas" (Ptolomeu, 2000, p. 68), princípio semelhante ao utilizado na técnica contemporânea da pestana no violão. 


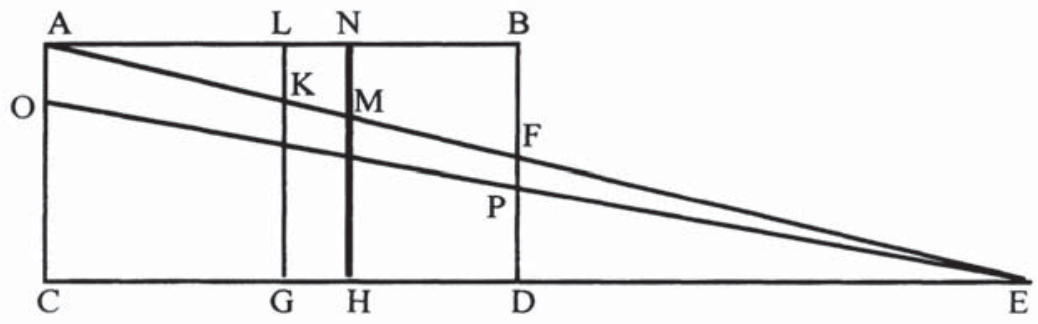

Figura 17. Diagrama do segundo instrumento de Ptolomeu, que parece servir-se do princípio do mesolábio.

Ptolomeu dá os detalhes musicais, materiais e geométricos de sua construção, na qual cada elemento tem uma função concreta. Como observa Barker,

ele não diz, por exemplo, "desenhamos linhas paralelas a AC, e uma linha ligando AFE”. Ele diz "nós esticamos as cordas paralelamente a AC (...) e colocamos debaixo delas o cavalete (...) AFE" (...) Enquanto a passagem do hélicon parece saída de um tratado de geometria, esse segundo instrumento parece mais um manual de como construir seu próprio instrumento (2000, p. 210).

No hélicon, a afinação é fixa e não pode ser alterada; o segundo instrumento parece ter sido construído para suprir essa dificuldade, além de permitir a medição de consonâncias emélicas e não apenas homofônicas e sinfônicas, isto é, intervalos menores que as consonâncias fixas. Contudo, ao final, Ptolomeu o considera de difícil manuseio, demonstrando uma vez mais que ele de fato esteve envolvido diretamente na sua construção e utilização (cf. Ptolomeu, 2000, p. 69).

No terceiro livro da Harmônica, Ptolomeu introduz um cânone de 15 cordas, instrumento de uso corrente em seu tempo, procurando fazer demonstrações a respeito da tensão e da densidade das cordas e revelar as razões dos intervalos emélicos. Além disso, Ptolomeu vê a necessidade de criar um sistema nos instrumentos para facilitar as constantes reafinações "que acontecem frequentemente na música realizada na cítara" (Ptolomeu, 2000, p. 132).

Portanto, assim como os instrumentos astronômicos utilizados por Ptolomeu foram essencialmente destinados a acompanhar a posição e o movimento dos planetas, na harmônica, eles têm a função de determinar as posições e os movimentos dos tons dentro dos sistemas, das escalas. 


\section{GÉu musical de Ptolomeu}

No livro 3 da Harmônica, Ptolomeu afirma que mostrou suficientemente seus argumentos nos dois primeiros livros e que isso aconteceu devido "às razões apropriadas de suas hipóteses e à luz do controle da performance real" (Ptolomeu, 2000, p. 138). Nesse livro, o autor deixará claro que, para ele, as hipóteses a partir das quais procedia a sua demonstração argumentativa eram os fundamentos inerentes ao próprio universo. O objetivo da sua harmônica é prover ferramentas de abordagem e interação com o mundo, possibilitando a observação dos princípios subjacentes àquilo que é perceptível.

De acordo com Donini, algumas passagens da Harmônica conectam-se diretamente ao livro Sobre o critério. Por exemplo, no Livro 3 da Harmônica, Ptolomeu discute conceitos como éthos, proporção, divindade, beleza natural e alma. Para Donini, o esquema de correspondências que ele desenvolve, relacionando intervalos musicais às partes inteligentes da alma, "coincidem exatamente com a sua análise dos constituintes do pensamento de Sobre o critério" (1996, p.204).

Para Ptolomeu, as afinações e as notas devem ser encontradas na natureza, senão não será possível encontrar a harmonia "oculta" ao ouvi-las, e nem poderão ser repetidas eterna e identicamente, seja nos sistemas musicais, pela alma humana ou no sistema planetário. O sistema de correspondências entre astronomia e harmônica desabrocha magistralmente no Livro 3, em capítulos intitulados "Como a sucessão das notas é similar ao movimento longitudinal das estrelas", "Como o movimento das estrelas em altitude é comparável aos gêneros harmônicos" ou "Da similaridade dos tetracordes com os aspectos do Sol".

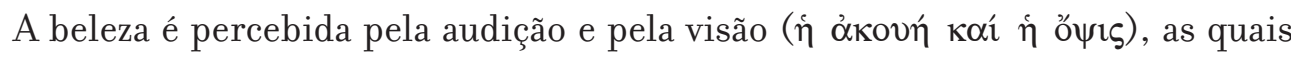
Ptolomeu toma como "irmãs", tal como Arquitas de Tarento (c. de 4,00 a 365 a.C.) havia tomado a astronomia e a música como ciências irmãs na obra Harmonia. 5 Para Ptolomeu, audição e visão se completam.

Por exemplo, o que é fornecido pela razão é mais ensinável e melhor lembrado por nós com diagramas e figuras, mas o que é reconhecido pela visão torna-se mais claro e melhor representado pela descrição poética (Ptolomeu, 2000, p. 141).

A ciência harmônica ptolomaica tem a tarefa de identificar os intervalos e as afinações do sistema grego, definindo o que é musical, ou seja, o que é belo sonoramente. Mas essa primeira etapa só é possível porque há uma coerência inteligível, matemáti-

5 “De fato, sobre a velocidade dos astros, sua ascensão e declínio, transmitiram-nos (os matemáticos) claros conhecimentos; também sobre geometria, ciência dos corpos celestes e não menos sobre música. Pois essas ciências parecem ser afins; pois se ocupam de coisas afins: as duas formas primeiras do ser" (Arquitas, 1973, p. 260). 
ca, na própria estrutura do universo. Os princípios da harmônica são os mesmos da astronomia e da cosmologia ptolomaica. A simplicidade tem um papel importante, pois "nós deveríamos buscar adaptar as hipóteses mais simples, na medida do possível, aos movimentos celestes, e se isso não der certo, tentar outras hipóteses possíveis" (Ptolomeu apud Lloyd, 1990, p. 150). Nesse sentido, Lloyd diz que há uma "continuidade essencial na teoria astronômica desde Ptolomeu até Copérnico, passando pelos astrônomos árabes" (1990, p. 151).

\section{Considerações finais}

O estudo atento da Harmônica de Ptolomeu mostra que ela é, na verdade, sua obra mais completa e, se de fato for a última, vem coroar o conjunto dela. Ali está reunido todo o seu conhecimento de música, acústica, matemática, física, astronomia, astrologia e filosofia.

A Harmônica foi comentada por Porfírio, servindo assim de fonte a Boécio no século vi. No século x, na Síria, Al Farabi também se interessou pela obra, tal como farão os bizantinos, responsáveis por sua preservação. No século xv, na Itália, Franchino Gaffurio a retoma em seu livro De harmonia musicorum instrumentorum e Zarlino, em meados do século seguinte, aprofunda questões da harmônica ptolomaica na obra Instituições musicais, defendendo apaixonadamente a afinação justa. No século xvıı, a harmonia ptlomaica está presente na Harmonices mundi de Johannes Kepler. A obra, agora, situa-se no centro de uma discussão acalorada entre cientistas, músicos e teóricos do Renascimento. $\mathrm{O}$ debate é acerca da questão da combinação ou não entre análise teórica e prática real, mas o que está em jogo, de fato, é a noção de harmonia universal.

Dahlhaus e Katz consideram que Ptolomeu tenha ensaiado rompimentos com a teoria dos intervalos matemático-ontológica, mas recuado no "passo final” ao dar-se conta de que, com o abandono das premissas pitagóricas mencionadas, havia o risco de não haver mais limites. "Se 5:4 é uma consonância, por que não 6:5, 7:6, 8:7 e etc., ad infinitum?" (Dahlhaus \& Katz, 1989, p. 268). Contudo, os autores concordam que seria "presunçoso culpar Ptolomeu por isso, por negar-se às consequências fatais daquilo que parece que intuiu" (p. 268).

Ptolomeu foi um verdadeiro coletor de dados e um dos maiores virtuoses do cálculo da Antiguidade, embora criticado contemporaneamente por seus erros de observação (cf. Solomon, 2000, p. xxvııI, n. 32). A expansão marítima e os avanços técnicos de observação levaram a astronomia ptolomaica ao declínio, assim como sua geografia. Contudo, no caso da harmônica, a coleta de dados é muito mais simples de ser feita e a sua representação não se transformou estruturalmente ao longo de milênios. 
Até hoje, utilizamos, na teoria musical, sistemas de organização presentes na harmônica aristoxeniana. Tudo isso leva a Harmônica de Ptolomeu a uma posição mais perene que o restante de sua obra.

Solomon, tradutor inglês da Harmônica, chamou a atenção para o design do tratado. Comparando-a com o Almagesto, o Tetrabiblos e a Geografia, ele percebeu um grande equilíbrio na sua organização e isso não seria uma coincidência, na medida em que é uma obra que descreve, e diríamos, mensura, a harmonia universal.

Três livros contendo 16 capítulos, cada livro contendo 8 assuntos, um para cada nota do diapasão homofônico. As primeiras quatro palavras harmônicas em um eco da tetrákys pitagórica (Solomon, 1990, p. 83).

Assim, podemos dizer que a forma da Harmônica reflete, ou ecoa, o seu conteúdo. De qualquer modo, consideramos que a Harmônica, definitivamente, não é uma obra menor de Ptolomeu, ela é o poema da ciência da harmonia universal, tal como conceberam os antigos. Ela não é um tratado a respeito de uma ciência particular, mas um discurso sobre a totalidade da filosofia, a investigação da natureza, a especulação e o saber ptolomaicos.

Agradecimentos. Agradeço ao Conselho Nacional de Desenvolvimento Científico e Tecnológico (CNPq) pela bolsa de doutorado concedida a partir de abril de 2011 junto ao Programa de Pós-Graduação do Departamento de Filosofia da Universidade de São Paulo.

Cynthia Gusmão Programa de Pós-Graduação em Filosofia, Departamento de Filosofia, Faculdade de Filosofia, Letras e Ciências Humanas, Universidade de São Paulo, Brasil. cygusmao@uol.com.br 


\section{ABSTRACT}

Music is an art with a special place in the technical domain, since from long ago musical performance made use of instruments. From Antiquity to modern era, musical instruments instigated acoustic investigations, and served both as devices for the observation of musical phenomena and as models for representing sound. The article expounds Ptolemy's approach in his Harmonics to the different methods of investigation involved, on the one hand, in the Pythagorean musical conception, with its arithmetical foundation and, on the other hand, the Aristoxenian conception, that puts musical phenomena into the same domain as human faculties like auditory perception and reason, while giving musical instruments a special role from both empirical and mathematical points of view. Harmonica is crucially important in bringing together a considerable part of science of harmonics in antiquity, and also going a step beyond this to expound the ancient conception of universal harmony.

KeYwords $\bullet$ Music. Harmonics. Pythagorism. Acoustics. Instrument. Aristoxenus. Helicon. Ptolemy.

\section{REFERÊNGIAS BIBLIOGRÁFIGAS}

Ackrill, J. L. (Ed.). A new Aristotle reader. Oxford: Clarendon Press, 1987.

Aristóteles. Posterior analytics. In: Ackrill, J. L. (Ed.). A new Aristotle reader. Oxford: Clarendon Press, 1987. p. 39-59.

. Physics. Harvard University Press: Loeb Classical Library, 1996.

Aristóxeno. Aristoxeni elementa harmonica. Roma: Typis Publicae Officinae Polygraphicae, 1954.

Arquitas. Fragmentos. Tradução I. L. Borges. In:VVAA. Os pré-socráticos. São Paulo: Abril Cultural, $197^{3}$. p. 260-1.

Barbera, A. (Ed.). Music theory and its sources. Antiquity and the middle ages. Notre Dame/Indiana: University of Notre Dame Press, 1990.

Barbour, M. Tuning and temperament. New York: Dover, 2004.

BARKer, A. Greek musical writings. Harmonic and acoustic theory. Cambridge: Cambridge University Press, 1989. v. 2.

. Scientific method in Ptolemy's harmonics. New York: Cambridge University Press, 2000.

BÉLIs, A. Aristoxène de Tarente et Aristote: le traité d'harmonique. Paris: Klincksieck, 1986.

Creese, D. Instruments and empicism in Aristoxenus. In: Huffman, G. A. (Ed.). Aristoxenus of Tarentum. New Jersey: Transaction Publishers, 2012. p. 29-64.

CRocker, R. L. Aristoxenus and greek mathematics. In: LA Rue, J. (Ed.). Aspects of medieval and renaissance music-a birthday offering to Gustave Reese. New York: W.W. Norton \& Company Inc., 1966. p. 96-110.

Dahlhaus, G. \& Katz, R. Contemplating music. New York: Pendragon Press, 1989. v. 2.

Dillon, J. \& Long, A. A. (Ed.). The question of “eclecticism”. Berkeley/Los Angeles: University of California Press, 1996.

Donini, P. The history of the concept of eclecticism. In: Dillon, J. \& Long, A. A. (Ed.). The question of “eclecticism". Berkeley/Los Angeles: University of California Press, 1996. p. 15-33.

Gibson, S. Aristoxenus of Tarentum and the birth of musicology. New York: Routledge, 2005 .

Gusmão, C.A harmônica na Antiguidade grega, São Paulo, 2010. Dissertação (Mestrado em Filosofia). Faculdade de Filosofia, Letras e Ciências Humanas, Universidade de São Paulo.

Huffman, C. A. (Ed). Aristoxenus of Tarentum. New Jersey: Transaction Publishers, 2012. 
La Rue, J. (Ed.). Aspects of medieval and renaissance music - a birthday offering to Gustave Reese. New York: W.W. Norton \& Company Inc., 1966.

LLoyd, G. E. R. The revolutions of wisdom - studies in the claims and practice of ancient greek science. Berkeley: University of California Press, 1987 . . Les science grecque après Aristote. Paris: Éditions La Découverte, 1990. . Methods and problems in greek science. Cambridge: Cambridge University Press, 1991.

Long, A.A. Ptolemy on the criterion: an epistemology for the practicising scientist. In: Dillon, J. \& Long, A. A. (Ed.). The question of "eclecticism". Berkeley/Los Angeles: University of California Press, 1996. p. $176-207$.

Mathiesen, T. Apollo's lyre. Nebraska: University of Nebraska Press, 1999.

Nicômaco de Gerasa. The manual of harmonics. Grand Rapids: Phanes Press, 1994.

Pseudo-Aristóteles. De audibilibus. In: Barker, A. Greek musical writings. Harmonic and acoustic theory. Cambridge: Cambridge University Press, 1989.v. 2. p. 98-109.

Pseudo-Euclides. The division of the canon. Lincoln: University of Nebraska Press, 1991.

Pтоцомеu, G. Las hipótesis de los planetas. Madrid: Alianza Editorial, 1987. . Harmonics. London: Brill, 2000.

Schueller, H. Idea of music: an introduction to musical aesthetics in antiquity and the middle ages. Michigan: Medieval Institute Publications, 1988.

Sedeño, E. P. Introducción. In: Pтоцомeu, G. Las hipótesis de los planetas. Madrid: Alianza Editorial, 1987. p. $9^{-} 5^{1 .}$

Solomon, J. A preliminary analysis of the organization of Ptolemy's Harmonics. In: Barbera, A. (Ed.). Music theory and its sources. Antiquity and the middle ages. Notre Dame/Indiana: University of Notre Dame Press, 1990. p. 68-84.

Introduction. In: Pтоцомeu, C. Harmonics. London: Brill, 2000. p. XXI-XxxviI.

Szaвó, A. Les débuts des mathématiques grecques. Paris: Vrin, 1977.

Treiler, L. (Ed.). Strunk's source reading in music history. New York: Norton Company, 1998.

WEBER, M. Fundamentos racionais e sociológicos da música. São Paulo: Edusp, 1995.

ZarLino, G. Le institutioni harmoniche. Venice, Italy. UNT Digital Library, 2012. Disponível em: <http:// digital.library.unt.edu/ark:/67531/metadc25955/>. Acesso em: 13 out. 2012. 